\title{
Nilai-Nilai Karya Cipta dan Problematik Perlindungan Hukumnya
}

\author{
M.Syamsudin .
}

\section{Abstract}

The following essay tries to address some issues related to patent right in Indonesia. It is found out from the study that the conception of patent right is not recognized in Indonesian traditional community. Demands for admitting and respecting the existence of patent right have to do with the influence of legal ideas from the School or Doctrine of Natural Law which heavily stresses on human factors and the use of mind which have been familiar and well known' in the system of civil law in European Continents. The concept of patent right, including its law protection in Indonesia, still faces various obstacles, specially cultural ones.

\section{Pendahuluan}

Manusia, inheren dalam dirinya diberi anugerah oleh Tuhan berupa alat kelengkapan yang sempurna berupa akal dan budi. Dengan akal dan budi tersebut manusia mampu berkarya cipta tentang sesuatu yang dikehendakinya. la mampu menciptakan ilmu pengetahuan, teknologi, dan juga seni yang sangat bernilai dan bermanfaat untuk. kehidupan manusia.

Dalam perkembangannya karya cipta yang bersumber dari hasil kreasi akal dan budi manusia tersebut telah melahirkan suatu hak yang disebut dengan hak cipta (copy right). Hak cipta tersebut melekat pada diri seorang pencipta atau pemegang hak cipta, sehingga lahirlah dari hak cipta tersebut hak-hak ekonomi (economic rights) dan hak-hak moral (moral rights). Hak ekonomi merupakan hak untuk mengeksploitasi yaitu hak untuk mengumumkan dan memperbanyäk suatu ciptaan; sedangkan hak moral merupakan hak yang berisi larangan untuk mélakukan perubahan terhadap isi ciptaan, judul ciptaan, nama pencipta, dan ciptaan itu sendiri. ${ }^{1}$

Dilihat dari sejarah perkembangannya, hak cipta lahir di benua Eropa pada' abad pertengahan yaitu pada zaman pericerahan tatkala semangat menggali pengetahuan

'Eddy Damian, 1999. Hukum Hak Cipta Menurut Beberapa Konvensi Internasional, UU Hak Cipta 1997, dan Perlindungannya terhadap Buku serta Perjanjian Penerbitan, Bandung: Alumni. HIm. 62-63. 
menjadi simbol dan pedoman masyarakat beradab (civilized society). Pencipta/penemu pada zaman ini dianggap sebagai pahlawan kemanusiaan yang disanjung dan diabadikan namanya. Zaman ini ditandai oleh semangat renaisance yang menolak terhadap kepasrahan, ketidakberdayaan yang terjadi pada zaman sebelumnya yang disebut zaman kegelapan. Menolak kegelapan dan kepasrahan berarti memberdayakan akal dan budi.

Dengan memberdayakan akal dan budi, maka muncullah penemuan-penemuan baru di bidang. ilmu dan teknologi seperti alat navigasi yang membawa manfaat bagi pengetahuan manusia tentang jagad raya, mesin cetak yang membawa akibat luar biasa pada cara-cara berkomunikasi, piston dengan uap panas yang mengilhami penemuan lainnya di bidang transportasi dan proses produksi. Penemuan-penemuan baru tersebut sebenarnya tidak berdiri sendiri, melainkan terkait dengan penemuan-penemuan sebelumnya. Papin, misalnya menemukan piston dengan uap panas (1690) tidak dapat lepas dari penemuan thermometer dengan prinsip uap air oleh Galileo (1620). Galileo sendiri juga tidak berangkat dari, nol, akan tetapi ia berhutang budi pada Leonardo de Vinci, Copernicus dan Kepler. ${ }^{2}$

Boleh jadi para pencipta/penemu di atas pada saat itu belum berpikir tentang hak cipta. Barangkali mereka mendapatkan inspirasi dari filsafat Yunani tentang hakekat manusia beradab yang mempunyai idealisme, lebih dari sekedar makhluk biologis dan fisiologis, sehingga memandang penemu dan pencipta sebagai pahlawan. Demikian juga para penemu/pencipta Muslim di zaman prareneisance Eropa, seperti Ibnu Sina, Ibnu Khaldun, Ibnu Rusyd, dan sebagainya. Mungkin mereka mencipta karena didorong oleh semangat iman dan taqwa dari ajaran Islam yang mengajarkan tentang keutamaan orang yang mempunyai ilmu pengetahuan. Dalam konteks ini sama sekali tidak relevan menuntut hak, karena mencipta dan menemukan adalah tujuan pemberdayaan untuk menjadi manusia yang beradab dan berbudaya.

Tuntutan untuk mengakui dan menghormati keberadaan hak (cipta) terkaitdengan pengaruh pemikiran hukum dari mazhab Hukum Alam yang sangat menekankan pada faktor manusia dan penggunaan akal seperti yang dikenal pada sistem hukum sipil (civil law system) Eropa Kontinental, termasuk juga Indonesia. ${ }^{3}$ Mazhab hukum alam ini telah mempengaruhi pemikiran hukum terhadap seseorang individu yang menciptakan pelbagai ciptaan yang kemudian memperoleh perlindungan hukum atas ciptaan yang merupakan kekayaan intelektual. Hak cipta merupakan bagian dari sekumpulan hak yang dinamakan hak kekayaan intelektual (HKI) yang pengaturannya terdapat dalam ilmu hukum yang dinamakan Hukum HKI. Hukum HKI meliputi suatu bidang hukum yang membidangi hak-hak yuridis dari

"Imam Buchori Zainudin. "Konsepsi Seni Rupa dalam Kaitannya dengan Hak Cipta", makalah pada Temu Wicara Mengenai Hak Cipta antara Seniman, Sastrawan, Ilmuwan, dan Organisasi Profesi di Bidang Hak Cipta, Jakarta: 28-29 Juli 1997, HIm. 1

${ }^{3}$ Satjipto Rahardjo. 1982. IImu Hukum. Bandung: Alumni. HIm. 292; 
karya-karya atau ciptaan-ciptaan hasil olah pikir manusia berkaitan dengan kepentingankepentingan yang bersifat ekonomi dan moral.

Hukum HAKI mencegah dilakukannya tindakan penjiplakan atau plagiat, yaitu suatu tindakan dengan maksud menarik keuntungan dari ciptaan-ciptaan yang merupakan kekayaan intelektual seseorang. Hukum HKI juga menetapkan kaidah-kaidah hukum yang mengatur ganti rugi yang harus dipikul oleh orang yang melanggarnya dengan melakukan tindakan penjiplakan. ${ }^{4}$

Berkaitan dengan perlindungan hukum atas hak cipta yang merupakan bagian dari HKl, Ricketson (1991) mengemukakan: ${ }^{5}$

"... it has been popular to argue, particularly in Continental jurisdiction, that a person has a natural property right in the creation of mind. Thus, it said; a person has a natural right to the product of his labour and this should be recomized as his property, whether tangible or intangible. With respect to copyright, it has been said that this theory sees the foundation of the rights of an author in the very nature of things."

- Senada dengan yang dikemukakan Ricketson, Deklarasi Universal Hak-Hak Asasi Manusia Pasal 27 ayat 1, menetapkan:

"Setiap orang mempunyai hak sebagai pencipta: untuk mendapatkan perlindungan atas kepentingan-kepentingan moral dan material yang merupakan hasil dari ciptaannya di bidang ilmu pengetahuan, sastra dan seni."

Meskipun sudah menjadi isu-isu global, terutama setelah persetujuan TRIPs di mana Indonesia menjadi salah satu negara yang ikut menandatangani persetujuan tersebut, masalah hak cipta di Indonesia masih menjadi permasalahan yang kompleks, penuh paradoks, ambiguitas, dan dilema. Hal ini dapat ditunjukkan, antara lain bahwa hak cipta merupakan hak eksklusif (khusus), yang mana bila dilihat dari akar budaya bangsa Indonesia, dapat dikatakan tidak mempunyai akar dalam kebudayaan Indonesia dan juga tidak terdapat dalam sistem hukum adat. ${ }^{6}$ Nilai-nilai falsafah yang mendasari pemilikan individu terhadap suatu karya cipta manusia baik dalam bidang ilmu, sastra, maupun seni adalah nilai budaya barat yang menjelma dalam sistem hukumnya ${ }^{7}$ Dikarenakan hak cipta tersebut bukan berasal dari nilai-nilai budaya bangsa Indonesia, akan tetapi nilai-nilai barat yang menjelma dalam sistem hukum keperdataannya, kadangkala pemberlakuan hak tersebut dalam kehidupan masyarakat menimbulkan pertentangan dengan nilai-nilai budaya tradisional yang telah melembaga dalam kehidupan masyarakat. Artinya, ada perbuatan yang dikualifikasikan sebagai pelanggaran hak cipta menurut ketentuan undang-undang, akan tetapi dalam

${ }^{4}$ Eddy Damian, Op.Cit. Hlm. 32-33

sLoc. Cit.

${ }^{6}$ yaitu hukum Indonesia asli yang tidak tertulis dalam bentuk perundang-undangan RI yang di sana-sini mengandung unsur agama, periksa, Hiilman Hadikusuma, 1992, Pengantar IImu Hukum Adat Indonesia, Bandung: CV Mandar Maju,HIm. 32

'Salman Luthan, 1989. "Delik Hak Cipta". Makalah Diskusi Jurusan Hukum Pidana FH UII, Tanggal 24 Agustus 1989, Hlm. 36 
nilai-nilai budaya masyarakat tersebut tidak dianggap sebagai suatu pelanggaran hak cipta. ${ }^{8}$ Demikian juga tentang konsep yang menyangkut perlindungan hak cipta bukan merupakan ide yang dimiliki bangsa Indonesia. ${ }^{9}$

\section{Konsep Dasar Hak Cipta dan Nilai-Nilai yang Terkandung di dalamnya}

Hak cipta merupakan istilah hukum untuk menyebut atau menamakan hasil kreasi atau karya cipta manusia dalam bidang ilmu pengetahuan, sastra, dan seni. Istilah tersebut adalah terjemahan dari istilah Inggris, yaitu copyright, yang padanan dalam bahasa Belanda adalah auteurrecht. Para pihak yang terkait langsung dengan hak cipta adalah kaum ilmuwan, sastrawan, dan seniman. ${ }^{10}$

Hak cipta sebagai bagian dari HKI, semula dikenal di negara yang menganut sistem Common Law, dipakai untuk menggambarkan hak penggandaan dan atau perbanyakan suatu karya cipta (copyright). Hak cipta dalam konsep common law adalah perlindungan karya sastra dan karya seni). Dalam pandangan common law system, hak cipta merupakan functionalist justification yaitu memandang hak cipta sebagai instrumen ekonomi dan kebijaksanaan untuk meningkatkan pengetahuan -dan mendukung perkembangan sosial ekonomi. Tujuan hak cipta adalah insentif bagi produser, penerbit dan promotor yang telah mengambil risiko guna pemasaran dan penjualan karyakarya cipta. Di Inggris, hak cipta berkembang untuk menggambarkan konsep guna melindungi penerbit dari tindakan penggandaan buku oleh pihak-pihak lain yang tidak mempunyai hak untuk menerbitkannya. Perlindungan diberikan bukan kepada si pencipta (author), akan tetapi kepada penerbit untuk memberi jaminan atas investasi penerbit dalam membiayai percetakan suatu karya. Dalam perkembangannya perlindungan tidak hanya diberikan kepada penerbit, akan tetapi juga kepada pencipta."

Di dalam konsep Civil Law System, hak cipta merupakan natural right justification yang memandang hak cipta sebagai suatu hak-hak dasar yang diberikan kepada si pencipta tanpa melihat konsekuensi ekonomi dan politik yang lebih luas. Tujuan hak cipta adalah memberikan reward (penghargaan) bagi si pencipta dan ini merupakan argumen moral. Hal ini adalah author's right system yaitu penekan perlindungan personality pencipta melalui ciptaanya lebih dari pada perlindungan terhadap karya cipta itu sendiri. ${ }^{12}$

Di Indonesia, yang mewarisi tradisi civil law, hak cipta dirumuskan sebagai hak khusus bagi pencipta atau penerima hak untuk mengumumkan atau memperbanyak

\section{$8 /$ bid.}

'Saidin, 1995. Aspek Hukum Hak kekayaan Intelektual (Intelectual Property Right), Jakarta PT Raja Grafindo Persada, HIm. 27.

'Salman Luthan, 1989. "Delik-Delik Hak Cipta". Makalah Diskusi Dosen Fakultas Hukum Ull Yogyakarta, HIm. 1.

"Rahmi Jened. 2001. Perlindungan Hak Cipta Pasca Persetujuan TRIPs. Surabaya: Yuridika Press Fak. Hukum Unair Surabaya. Him. 25-26.

${ }^{12}$ /bid. 
ciptaannya maupun memberi ijin untuk itu. Dalam sistem hukum di Indonesia, pengaturan tentang hak cipta ini merupakan bidang hukum perdata, yang termaśuk dalam bagian hukum benda. Khusus mengenai hukum benda terdapat. pengaturan tentang hak-hak kebendaan. Hak kebendaan itu sendiri terdiri atas hak kebendaan materiil dan hak kebendaan immateriil. Termasuk dalam hak kebendaan immateriil adalah hak kekayaan intelektual (intellectual property right), yang terdiri atas hak cipta (copyright) dan hak kekayaan industri (industrial property right). ${ }^{13}$ Hak cipta sendiri mencakup dua bagian yaitu: hak cipta dan hak yang berkaitan dengan hak cipta (neigbouring right), sedangkan hak milik industri mencakup hak paten, model dan rancang bangunan (utility models), desain industri (industrial design), merek dagang (trade mark), nama niaga dan nama dagang, sumber tanda atau sebutan asal (indication of source or appelation of origin).$^{14}$

Adapun standar agar dapat dinilai sebagai hak cipta (standart of copyright ability) atas karya cipta di bidang ilmu pengetahuan, seni dan sastra yaitu: (1) perwujudan (Fixation), yaitu suatu karya diwujudkan dalam. suatu media ekspresi yang berujud manakala pembuatannya ke dalam perbanyakan atau rekaman suara oleh atau berdasarkan. kewenangan pencipta, secara permanen atau stabil untuk dilihat, direproduksi atau dikomunikasikan dengan cara lain, selama suatu jangka waktu yang cukup lama; (2) keaslian (originality), yaitu karya cipta tersebut bukan berarti harus betul-betul baru atau unik, mungkin telah menjadi milik umum akan tetapi masih juga asli; dan (3) kreativitas (creativity), yaitu karya cipta tersebut membutuhkan penilaian kreatif mandiri dari pencipta dalam karyanya yaitu kreativitas tersebut menunjukkan karyà asli. ${ }^{15}$

Hak cipta dewasa ini telah menjadi masalah internasional yang bertujuan untuk menentukan arah politik hubungan antar bangsa, politik ekonomi, politik pertahanan, dan politik budaya. Hak cipta, dan juga hak hak lain seperti paten, dan merek dipakai sebagai alat ukur untuk menentukan status sebuah negara maju, berkembang atau terbelakang, terutama dalam hal penentuan tinggi rendahnya royalti. Hak cipta dewasa ini telah mampu menyumbangkan sesuatu yang bernilai budaya, nilai ekonomi, nilai estetik, nilai kreatifitas, dan nilai sejarah sehingga mampu menambah pendapatan negara.

Nilai ekonomi dari hak cipta pada hakekatnya memberikan perlindungan bagi si pencipta untuk menikmati secara materili jerih payahnya dari karya cipta tersebut. Benda hasil karya cipta dianggap sebagai benda bergerak yang dapat diperjualbelikan, diwariskan, dan dihibahkan. Suatu contoh misalnya Seorang pematung menciptakan sebuah patung dari bahan marmer berukuran 1:1, diaksanakan. selama 2 (dua) bulan. Setelah selesai kemudian

${ }^{13}$ Saidin, 1995. Aspek Hukum Hak Kekayaan Intelektual (Intellectual Property Right), Jakarta: PT Raja Grafindo Persada, HIm. 3

${ }^{14} / \mathrm{bid}$. HIm. 10

${ }^{-15}$ Earl W.Kintner dan Jack Lahr. 1983. An Intellectual Property Law. Primer. New York: Clark Boardman. HIm. 346-349 
dipamerkan, mendapat pujian dari kritikus. Tetkala dijual harganya mencapai Rp.50 jutà. Contoh lain adanya nilai ekonomi yang tinggi dari hak cipta misalnya sengketa Microsoft dengan perusahiaan kecil pembuat disket piranti lunak bernama Stac Electronics yang berakhir dengan kesediaan Microsoft membayar ganti rugi kepada Stac. Electronics sebesar US $\$ 82$ Juta sebulan selama kurun waktu 43 bulan karena membajak teknologi Stac Electronics. ${ }^{16}$

Beberapa data dalam besaran cukup besar yang merupakan nilai ekonomi dari karya cipta dapat disimak dari berita dalam Publisher Weekly Edisi 22 Pebruari 1999. Diberitakan bahwa pembajak global pada tahun 1998 senilai US\$12,38 milliar (99 triliun). Angka ini naik $6 \%$ dibanding tahun sebelumnya (1977) yang mencapai angka UŚ\$. 11,69 milliar. International Intellectual Property Alliance (IIPA) juga memberikan data-data yang menunjukkan bahwa karya-karya di Amerika Serikat yang paling dibajak adalah aplikasi Software, yakni senilai US $\$ 4,65$ milliar, urutan kedua adalah entertainment program senilai US $\$ 3,4$ milliar. Sedangkan kerugian para penerbit Amerika Serikat akibat tindakan pembajakan Copyright-nya sebesarUS $\$ 685,3$ juta (1998) lebih besar US $\$ 20$ juta dibanding tahun sebelumnya yakni US $\$ 665,3$ juta (1997). menurut IIPA, negara pembajak terbesar yang telah merugikan penerbit karena melakukan pembajakan copyright adalah China (US $\$ 125$ juta), Rusia (US\$ $\$ 5$ juta), Pakistan (US $\$ 40$ juta), Philipina (US\$.39 juta), Ǩorea dan Meksiko-(masing-masing US\$ 35 juta), India dan Indonesia (US\$ 30 juta). ${ }^{17}$

Suatu karya cipta juga mempunyai nilai budaya dan estetis manakala mampu mengusik emosi, inspirasi, dan penuh pesan. Dalam hal ini kualifikasi harga tidak diperhitungkan, akan tetapi yang diperiizungkan adalah faktor estetis dan pengakuan masyarakat terhadap si pencipta: Penilaian terhadap karya cipta yang mempunyai bobot budaya dan estetis. tidak mudah, dibutuhkan keahlian profesional yang mampu mengungkap nilai-nilai tersebut. Biasanya ditangani oleh kritikus dan kurator. Lembaga-lembaga lelang karya seni yang terkenäl selalu menggunakan jasa kurator untuk melihat keaslian karya, kandungan nilai budaya dan keaslian karya.' -

Suatu karya cipta juga sering mengandung nilai sejarah. Misalnya pelukis Indonesia pertama Räden Saleh yang melukiskan perkelahian Banteng dan Harimau. Lukisan Raden Saleh mengandung dimensi kesejarahan. Di balik lukisannya tersembunyi suatu pergolakan batin yang melambangkan gejolak perjuangan yang bernuansa pembebasan, terutama sejarah perjuangan Indonesia.

\section{Prinsip-Prinsip Dasar Perlindungan Hak Cipta}

Prinsip-prinsip dasäryang dapat digunakan untuk perlindungan hak cipta adalah sebagai berikut:

${ }^{16}$ Suara Pembaharuan, 27 Juni 1994.

${ }^{17}$ Siaran. IKAPI No.04/Tahun III, April-Mei 1999, yang memuat Artikel Amar Faishal dalam rubrik Info untuk Anda, HIm. 5, dalam Edy Damian, Loc.Cit. HIm. 5-6. 
1. Yang dilindungi adalah ide yang telah berwujud dan asii.

Prinsip ini mengandung arti bahwa hak cipta hanya berkenaan dengan bentuk perwujudan dari suatu ciptaan seperti buku, sehingga tidak berkaitan dengan substansinya. Prinsip ini melahirkan sub prinsip antara lain: (1) prinsip keaslian (orisinil) yaitu bahwa suatu ciptaan harus mempunyai keaslian untuk dapat menikmati hak-hak yang diberikan undang-undang. Keaslian ini sangat erat hubungannya dengan bentuk perwujudan suatu ciptaan. Oleh karena itu suatu ciptaan dapat dianggap asli bila bentuk perwujudannya tidak berupa suatu jiplakan (plagiat) dari suatu ciptaan lain yang telah diwujudkan; (2) prinsip bahwa suatu ciptaan mempunyai hak cipta jika ciptaan yang bersangkutan diwujudkan dalam benntuk tulisan atau bentuk material yang lain. Ini berarti bahwa suatu ide atau gagasan atau cita-cita belum merupakan suatu ciptaan; (3) prinsip bahwa hak cipta adalah hak khusus dari pencipta atau penerima hak untuk mengumumkan atau memperbanyak ciptaannya. Ini berarti bahwa tidak ada orang lain yang boleh melakukan hak itu kecuali dengan izin pencipta. Hak khusus ini mengandung arti "monopoli terbatas" techadap bentuk perwujudan dari ide pencipta, bukan terhadap ide itu sendiri.

\section{Hak cipta timbul dengan sendirinya} (otomatis)

Ini berarti bahwa suatu hak cipta eksis pada saat pencipta mewujudkan idenya dalam suatu bentuk yang berujud, misal buku. Untuk memperoleh hak cipta tidak diperlukan tindakan lanjutan apapun. Pendaftaran (di Dep. Kehakiman) tidak mutlak harus dilakukan. Jika pendaftaran dilakukan, akan mempermudah pembuktian kepemilikan hak cipta oleh pencipta dalam hal terjadinya sengketa tentang hak cipta: Dengan adanya wujud dari suatu ide maka hak cipta lahir. Ciptaan yang dilahirkan dapat diumumkan dan dapat tidak diumumkan. Suatu ciptaan yang tidak diumumkan, hak ciptanya tetap ada pada pencipta.

3. Suatu ciptaan tidak selalu perlu diumumkan untuk mendapatkan hak cipta

Suatu ciptaan yang diumumkan maupun yang tidak diumumkan keduanya dapat memperoleh hak cipta. Misalkan seorang pencipta suatu naskah tulisan menyimpan naskahnya di dalam laci meja tulisnya tanpa adanya usaha mengumumkan sendiri lewat penerbit. Walaupun tidak diumumkan hak cipta naskah tulisan tersebut tetap ada pada pencipta. Lain halnya dengan suatu susunan perwajahan karya tulis yang hak ciptanya baru timbul sesudah suatu pengumuman dilakukan (Pasal 11 ayat (1) a UUHC 97). Susunan perwajahan karya tulis baru mempunyai hak cipta bagi penerbit setelah penerbitan dilakukan olehnya, yang berarti setelah diumumkan.

4. Hak cipta suatu ciptaan merupakan suatu hak yang diakui hukum yang harus dipisahkan dan harus dibedakan dari penguasaan fisik suatu ciptaan.

Ini berarti bahwa seseorang yang membeli sebuah buku dari toko buku misalnya, ia menjadi pemilik buku tersebut. Namun ia bukanlah pemilik hak cipta dari ciptaan tulisan yang diterbitkan dan dicetak dalam buku yang dibelinya. Apabila orang tersebut kemudian memperbanyak buku yang dibelinya dalam 
jumlah besar untuk dikomersialkan, ia melanggar hak cipta.

5. Hak cipta bukan hak mutlak (absolut).

Hak cipta bukan suatu monopoli mutlak melainkan hanya suatu limited monopoly. Ini berarti bahwa jika terjadi penciptaan dalam waktu yang sama (coincidence) tidaklah terjadi plagiat sehingga bukan merupakan pelanggaran hak cipta. Dalam kasus demikian tidak terjadi penjiplakan atau plagiat asalkan ciptaan yang tercipta kemudian tidak merupakan duplikasi atau penjiplakan murni dari ciptaan terdahułu. ${ }^{18}$

\section{Perlindungan Hukum Karya Cipta}

Perlindungan hukum mengacu kepada norma-norma hukum baik tertulis maupun tidak tertulis yang mengatur hubungan antar manusia dalam berbagai aspek kehidupan, yang bertujuan untuk menjaga ketenteraman dan ketertiban hidup bermasyarakat, memberikan perlindungan terhadap hak-hak dan kepentingan manusia, dan sarana untuk menegakkan keadilan. Dengan adanya aturan hukum, maka setiap orang mempunyai pedoman dalam bertingkah laku. Hukum memberikan batasan-batasan terhadap bentuk-bentuk tingkah laku yang tidak boleh dilakukan disertai ancaman hukuman bagi orang yang melanggarnya.

Norma-norma hukum yang mengatur perlindungan terhadap hasil karya cipta manusia dapat dijadikan dasar melindungi hak cipta. Norma-norma hukum tersebut dápat dijadikan dasar dan alasan untuk menuntut atau menggugat apabila ketentuan atau norma hukum hak cipta tersebut dilanggar dari usaha-usaha pencurian, penjiplakan dan pembajakan.

Ketentuan hukum yang berkaitan dengan karya cipta ada yang bersifat internasional dan nasional. Ketentuan hukum yang bersifat internasional antara lain: Konvensi Bern 1886 tentang Perlindungan Karya Sastra dan Seni (The Beme Convention for The Protection of Literry and Artistic Works), Konvensi Hak Cipta Universal 1952 (The Universal Copyright Convention 1992), Konvensi Roma 1961 tentang Perlindungan Pelaku Produser Rekaman dan Lembaga Penyiaran (Rome Convention for the Protection of Performers, Producers of Phonograms and Broadcasting Organization), Konvensi Jenewa 1971 tentang perlindungan Produser Rekaman Suara dan Perbanyakan Tidak Sah Rekaman Suara (Genewa Convention for the Protection of Producers of Phonograms againts Unauthorized Duplication of Their Phonograms), Persetujuan tentang Aspek-aspek Dagang yang terkait dengan Hak-hak Atas Kekayaan Intelektual 1994 (Agreement on Trade Related Aspects of Intellectual Property RightsTRIPS).

Pengaturan hukum tentang hak cipta di Indonesia sebenarnya sudah dimulai sejak zaman penjajahan Belanda yaitu sejak tahun 1912, berdasarkan 'Auteurswet 1912' (St.1912 No.600)..$^{19}$ Baru kemudian kurang lebih 70

${ }^{18}$ Eddy Damian, Loc.Cit. HIm. 98-105;

${ }^{19}$ M. Jumhana dan R Djubaediliah. 1993. Hak Milik Intelektual sejarah, Teori dan Prakteknya. Bandung: Citra Aditya Bhakti. HIm. 39 
tahun setelah kemerdekaan RI, bangsa Indonesia mempunyai perundang-undangan nasional yang mengatur tentang hak cipta yaitu tepatnya pada tahun 1982, dengan diundangkannya UU No. 6. Tahun $19 \overline{9} 82$ tentang Hak Cipta (L.N.RI, 1982 No.15 dan TLN. No.3217). ${ }^{20}$ Dengan diundangkannya UU No.6 Tahun 1982, maka secara resmi Auteurswet 1912 tidak berlaku lagi karena dirasa sudah tidak sesuai dengan kebutuhan dan cita-cita hukum nasional.

Kurang lebih lima tahun sejak UU No.6/ 1982 diberlakukan, beberapa ketentuan dalam UU tersebut diubah, dihapus dan ditambah, yaitu dengan diundangkan UU No.7 Tahun 1987 tentang perubahan atas UU No.6/1982 tentang Hak Cipta. Perubahan tersebut disebabkan adanya masalah yang timbul antara lain:

1) Meningkatnya jumlah pelanggaran hak cipta (seperti pembajakan) yang dirasakan telah sampai padà tingkat yang membahayakan;

2) Ancaman pidana terlălu ringàn, yang dianggap kurang mampu di dalam menangkal pelanggaran hak cipta;

3) Dirasakan kuranignya koordinasi dan kesamaan pandangan; sikap, serta tindakan di antara aparat penegak hukum dalam menghadapi masalah pelanggäran hak cipta;
4) Masih kurangnya tingkat pemahaman. mengenai arti dan fungsi hak cipta serta ketentuan-ketentuan undang-undang hak cipta di kalangan masyarakat pada umumnya, dan bahkan di kalangan pencipta pada khususnya. ${ }^{21}$

Di samping itu seiring dengan tuntutan globalisasi dan keikutsertaan Indonesia dalam persetujuan-persetujuan internasional, terutama terkait dengan persetujuan tentang Aspek-aspek Hak atas Kekayaan Intelektual (HAKI) yang terkait dengan perdagangan(Agreement on Trade Related Aspects of Intellectual Property Rights-TRIPS) yang merupakan bagian dari persetujuan. pembentukan organisasi perdagangan dunia (Agreement Establishing the World Trade: Organization), telah diratifikasi UU.No.7 Tahun 1994. Konsekuensinya, Indonesia harus melakukan harmonisasi ketentuan-ketentuan perundangan nasional dengan ketentuanketentuan yang ada di dalam TRIPs tersebut.

Salah satu upaya harmonisasi tersebut adalah dengan diundangkannya UU No.12 Tahun 1997 tentang Perubahan atas UndangUndang No..6 Tahun 1982 tentang Hak Cipta sebagaimana telah diubah dengan UU No.7 Tahun $1987 .{ }^{22}$ Dengan demikian lahirnya UU No.12/1997 merupakan tuntutan internasional dan upaya pemerintah Indonesia dalam melakukan harmonisasi hukum $\mathrm{HAKI}$ di bidang

\footnotetext{
${ }^{20}$ Sophar Maru Hutagalung, 1994. Hak Cipta Kedudukan dan Peranannya di dalam Pembangunan. Edisi pertama, Jakarta: Akademika Pressindo, HIm. 103.

${ }^{21} /$ bid. HIm. 110-112.

22Nandang Sutrisno, 1999. "Implementasi Persetujuan TRIPs dalam Undang-Undang Hak Cipta Indoṇesia," Jurnal Hukum No.12 Vol. 6-1999, HIm. 46.
} 
hak cipta, berkaitan dengan keikutsertaan Indonesia dalam WTO dan TRIPs.

TRIPs sebenarnya merupakan isu baru dalam persetujuan umum tentang tarif dan perdagangan (General Agreement on Tariff and Trade - GAAT) yang dimasukkan melalui Putaran Uruguay yang berjalan dari tahun 1986 sampai tahun 1994. Masuknya masalah HAKI ke dalam GAAT, sebenarnya merupakan usulan dari negara-negara industri agar HAKI mereka lebih terjamin perlindungannya dalam globalisasi perdagangan. Mereka memandang bahwa mekanisme penyelesaian sengketa melalui GAAT akan lebih efektif karena dimungkinkan untuk melakukan pembalasan (retaliation) dan pembalasan silang (cross retaliation) yang berupa sanksi-sanksi perdagangan yang dikenakan terhadap barang-barang ekspor negara yang melakukan pelanggaran. ${ }^{23}$

\section{Ruang Lingkup Perlindungan Hak Cipta}

Dalam pasal 11 UU No. 12/ 97 ditetapkan ketentuan sebagai berikut:

(1) Dalam undang-undang ini yang dilindungi adalah ciptaan dalam bidang iimu pengetahuan, seni, dan sastra; yang meliputi karya:

a. buku, program komputer, pamflet, susunan perwajahan karya tulis yang diterbitkan, dan semua hasil karya tulis lainnya;

b. ceramah, kuliah, pidato, dan ciptaan lainnya yang diwujudkan dengan cara diucapkan; c. alat peraga yang dibuat untuk keperluan ilmu pengetahuan;

d. ciptaan lagu atau musik dengan atau tanpa teks, termasuk karawitan, dan rekaman suara;

e. drama, tari (koreografi), pewayangan, pantomim;

f. karya pertunjukan;

g. karya siaran;

h. seni rupa dalam segala bentuk seperti lukisan, gambar, seni ukir, seni kaligrafi, seni pahat, seni patung, kolase, seni terapan yang berupa seni kerajinan tangan;

i. arsitektur,

j. peta;

k. seni Batik;

l. fotografi;

m. sinematografi;

n. terjemahan, tafsir, saduran, bunga rampai, dan karya lainnya dari hasil pengalihwujudan.

(2) Ciptaan sebagaimana dimaksud dalam huruf $n$ dilindungi sebagai ciptaan tersendiri dengan tidak mengurangi hak cipta atas ciptaan aslinya;

(3) Dalam perlindungan sebagimana dimaksud dalam ayat (1) dan (2) termasuk juga semua ciptaan yang tidak atau belum diumumkan, akan tetapi sudah merupakan suatu bentuk kesatuan yang nyata yang memungkinkan perbanyakan karya tersebut.

Meskipun karya cipta yang disebutkan di atas mendapatkan periindungan hukum, akan

${ }^{23}$ Martin Khor Kok Peng, 1993. Imperialisme Ekonomi Baru: Putaran Uruguay dan Kedaulatan Dunia Ketiga, Jakarta: PT Gramedia Pustaka Utama dan Konphalindo, HIm. 31. 
tetapi undang-undang juga memberikan pembatasan terhadap hak cipta. Pembataspembatasan tersebut diatur pada Pasal 13 dan 14 UU No.12/1997. Ketentuan Pasal 13 menentukan hal-hal yang dianggap bukan sebagai pelanggaran hak cipta, yaitu:

1) Pengumuman dan perbanyakan dari lembaga negara dan lagu kebangsaan menurut sifat aslinya;

2) Pengumuman dan perbanyakan dari segala sesuatu yang diumumkan oleh atau atas nama pemerintah, kecuali apabila hak cipta itu dinyatakan dilindungi, baik dengan peraturan perundang-undangan maupun dengan pernyataan pada ciptaan itu sendiri atau ketika ciptaan itu diumumkan;

3) Pengambilan, baik seluruhnya maupun sebagian, berita dari kantor berita, badan penyiar radio atau televisi dan surat kabar dan surat kabar setelah satu kali dua puluh empat jam terhitung dari saat pengumuman pertama berita itu dan sumbernya harus disebut secara lengkap.

Kemudian Pasal 14 menentukan bahwa asalkan sumbernya disebutkan atau dicantumkan, maka tidak dianggap sebagai pelanggaran hak cipta, yaitu:

1) Penggunaan ciptaan pihak lain untuk keperluan pendidikan, penelitian, penulisan ilmiah, penyusunan laporan, penulisan kritik dan tinjuan suatu masalah dengan ketentuan tidak merugikan kepentingan yang wajar bagi pencipta;

2) Pengambilan ciptaan pihak lain baik seluruhnya maupun sebagian guna keperluan pembelaan di dalam dan di luar pengadilan;
3) Pengambilan ciptaan pihak lain baik seluruhnya maupun sebagian guna kepertuan: (1) ceramah yang semata-mata untuk tujuan pendidikan dan ilmu pengetahuan; (2) pertunjukan atau pementasan yang tidak dipungut bayaran dengan ketentuan tidak merugikan kepentingan yang wajar bagi pencipta;

Perbanyakan suatu ciptaan dalam bidang ilmu, seni, dan sastra dalam huruf braile guna keperluan tuna netra, kecuali jika. perbanyakan itu bersifat komersial;

4) Perbanyakan suatu ciptaan selain program komputer, secara terbatas dengan cara atau alat apapun atau proses yang serupa oleh perpustakaan umum, lembaga ilmu pengetahuan atau pendidikan dan pusat dokumentasi yang non komersial' sematamata untuk kepertuan aktifitasnya;

5) Perubahan yang dilakukan atas karya arsitektur seperti ciptaan bangunan berdasarkan pertimbangan pelaksanaan teknis;

6) Pembuatan suatu salinan cadangan suatu program komputer yang dilakukan sematamata untuk digunakan untuk keperluan sendiri.

Dengan adanya perlindungan hukum tersebut berarti hak dan kepentingan pencipta diakui dan dilindungi oleh undang-undang, sehingga mereka dapat menuntut setiap orang yang melanggar hak dan kepentingannya atas karya cipta tersebut. Upaya hukum untuk menuntut para pelanggar hak cipta dapat dilakukan oleh pencipta atau organisasi yang terkait dengan ciptaan tersebut, melalui tuntutan pidana atau gugatan perdata.

Berdasarkan uraian tentang perlindungan hukum hak cipta dapat diketahui bahwa 
ketentuan-ketentuan hukum yang mengatur tentang hak cipta dengan segala aspeknya sudah cukup memadai dan mendukung perlindungan hak cipta. Ketentuan-ketentuan hukum tersebut berbentuk Konvensi-konvensi Internasional yaing berlaku universal, dan undang-undang yang bersifat nasional (UU Hak Cipta No.12/1997).

Perlindungan hukum terhadap berbagai jenis karya cipta mempunyai arti penting bagi para pencipta, seperti ilmuwan, sastrawan, novelis, pencipta lagu, pelukis, arsitek, aktor dan aktris, pembatik, dan sebagainya. Di samping itu perlindungan hukum juga mempunyai arti yang sama bagi organisasi dan lembaga yang bergerak dan terkait dengan cipta mencipta, seperti IKAPI, ASIRI, PARFI, OPI, dan sebaginya.

Untuk memperkuat perlindungan hukum terhadap karya cipta maka sebaiknya hak cipta tersebut didaftarkan pada Departemen Kehakiman dan HAM. Namun demikian pendaftaran tersebut bukan merupakan kewajiban untuk mendaftarkan hak cipta. Pendaftaran hak cipta dalam daftar umum ciptaan tidak mengandung arti sebagai pengesahan atas isi, arti atau bentuk dari ciptaan yang didaftarkan. Hal itu berguna untuk memperkuat kedudukan hak cipta sebagai alat bukti apabila terjadi sengketa atau pelanggaran hak cipta.

Meskipun ketentuan hukum telah cukup memadai melindungi hak cipta, di dalam praktek di lapangan masih sering muncul beberapa permasalahan yang sekiranya perlu diberi jalan pemecahan. Permasalahan tersebut seperti akan disampaikan pada uraian berikut.

\section{Problematika Hak Cipta}

Problematik hak cipta muncul berkaitan dengan masalah liberalisasi ekonomi di satu pihak dan masalah kondisi sosial-budaya masyarakat Indonesia di pihak lain. Kondisi sosial-budaya masyarakat Indonesia masih dalam masa transisi industrial yang belum semuanya mengerti dan memahami masalah hak cipta yang sebelumnya tidak dikenal. Masyarakat transisi industrial digambarkan sebagai masyarakat yang sedang mengalami perubahan dari masyarakat agraris yang bercorak komunal-tradisional ke masyarakat industri yang bercorak individual-modern. Perubahan itu berkaitan dengan struktur hubungan masyarakat yang belum tuntas ke corak yang lebih rasional dan komersial sebagai akibat dari proses pembangunan yang dilakukan. ${ }^{24}$

Dalam masyarakat semacam itu, hukum yang mengatur juga mencerminkan masa peralihan yang digambarkan sebagai wajah hukum yang berpijak pada dua kaki dengan langkah yang berbeda, yakni satu kaki sedang melangkah pada corak hukum modern sementara kaki yang lain masih menapak pada hukum tradisional. Demikian halnya dengan hukum yang mengatur masalah hak cipta, meskipun secara normatif tidak banyak mengandung masalah untuk diberlakukan di Indonesia, akan tetapi secara kultural akan banyak mengalami problem dalam

${ }^{24}$ Maryadi, 2000. Transformasi Budaya. Ctk. Pertama. Surakarta: Muhammadiyah University Press, HIm. 53 
pelaksanaanya. Hal ini disebabkan oleh dasar filosofi yang melatarbelakangi masyarakat hukum itu berbeda. Hak cipta muncul di negara-negara barat bersamaan dengan munculnya masyarakat industri yang didasari corak masyarakat yang lebih mengedepankan kepentingan atau hak-hak individu (private rights) dengan watak kapitalistik, sementara masyarakat Indonesia dengan corak ketimuran lebih mengedepankan nilai-nilai kebersamaan (komunal). Hal ini berakibat pada pemikiran bahwa jika mereka berkarya dan hasil karyanya bermanfaat bagi orang banyak, mereka akan merasa bangga dan tidak begitu mempermasalahkan apabila ternyata orang lain menirunya, bahkan merasa telah diuntungkan karena hasil karyanya telah disebariuaskan dan dikenal oleh banyak orang. ${ }^{25}$

Berdasarkan hasil penelitian yang dilakukan oleh Absori terhadap industri tradisional di daerah pengrajin tembaga Boyolali dan industri batik Surakarta dihasilkan bahwa kebanyakan mereka tidak mempermasalahkan karyanya ditiru pihak lain dan tidak ada keinginan untuk menuntut secara hukum, sekalipun disadari bahwa perbuatan itu dapat merugikan usahanya. Terhadap adanya ketentuan untuk mendaftarkan karya cipta batik ke Kantor Cipta, Paten dan Merek di Jakarta, sebagaimana diatur oleh undang-undang, kebanyakan mereka tidak begitu berkepentingan untuk melakukan pendaftaran. Kalau ada yang melakukan pendaftaran, manfaat nyata belum dapat dirasakan secara langsung, karena ternyata karya yang sudah didaftarkan masih juga ditirü oleh pihak lain dan untuk melakukan penuntutan juga mengalarn ikesultan ${ }^{26}$ Demikian juga untuk karya cipta lagu dan musik, kesadaran untuk melakukan pendaftaran dinilai masih rendah. Padahal dari pendaftaran karya cipta lagu dan musik pihak-pihak yang tergabung dalam Yayasan karya Cipta Indonesia (YKCl) selama tahun 1996 dapat diperoleh dana royalty sebesar Rp. 2,3 milyar. Dana tersebut sebagian besar didistribusikan pada cipta lagu. ${ }^{27}$

Problem hak cipta juga muncul berkaitan dengan seni rupa tradisional Indonesia yang masih hidup seperti seni batik, seini pahat hiasan, ragam hias; keramik gerabah, anyaman rotan dan bambu. Permasalahannya, apakah seorang perancang batik térkenal yang membuat rancangannya berdasarkan pada pola dan ragam tradisional dapat menuntut pada pembatik-pembatik tradisional yang menulis batik mirip dengan rancangan pembatik terkenal tersebut karena menggunakan pola dan ragam hias yang sudah mentradisi dikarenakan pembatik terkenal tersebut sudah mendaftarkan karyanya pada Kantor Cipta, Paten dan Merek?

Kasus lain misalnya sentra-sentra kerajinan rotan di daerah Tegalwangi dan sentra kerajinan di Tasikmalaya yang sudah dikenal di masyarakat luas. Pengrajin tersebut pada umumnya lugas dan jujur. Sambil menawarkan pekerjaannya mengatakan dengan bangga bahwa desain dari barang tersebut dibuat oleh pendesain yang sudah
${ }^{25}$ Ibid.
${ }^{26} /$ bid.
${ }^{27}$ Jawa Pos, 20 Oktober 1997. 
dikenal di masyarakat luas. Justru karena faktor tersebut kemudian pedagang dan para eksportir memesan barang tersebut dalam jumlah besar. Dalam kasus ini hak moral dari pendesain telah diakui oleh pengrajin dengan menyebut siapa pendesainnya lantaran mentalitas mereka menaruh hormat dengan setulus hati pada orang yang mau menularkan 'ilmunya' pada orang lain. Dalam kasus itu pendesain harus menuntut siapa?

Di sisi lain, di masyarakat masih terdapat sebagian pencipta yang hasil ciptaanya justru senang ditiru, diperbanyak atau dipertunjukkan oleh orang lain kepada umum. Perbuatan seperti itu tidak merugikan kepentingan pencipta, akan tetapi sebaliknya justru akan mendatangkan keuntungan, yaitu semakin memasyarakatnya karya cipta mereka di kalangan masyarakat. Mereka memandang bahwa karya cipta tidak hanya semata-mata bernilai materi belaka, akan tetapi mempunyai nilai sosial dan religius. Mereka meyakini adanya nilai pahala yang dapat dipetik dari karya ciptanya. IImu yang dimiliki seseorang apabila dipelajari, diamalkan seseorang kepada orang lain, maka yang memiliki ilmu tersebut.akan mendapatkan pahala dari Sang Pencipta (Tuhan).

Budaya masyarakat tradisional di Indonesia tidak mengenal hak cipta. Nilai-nilai budaya masyarakat Indonesia tidak mengenal pemilikan individu terhadap suatu karya cipta dalam bidang ilmu pengetahuan, sastra, dan seni. Satu-satunya sistem pemilikan yang melembaga dalam kehidupan masyarakat tradisional adalah pemilikan tanah. Namun pemilikan itu sifatnya komunal, artinya dimiliki oleh keluarga atau masyarakat hukum adatnya. Keadaan ini nampak jelas dalam penghargaan atas kreativitas dan karya seni dalam masyarakat tradisional. Karya seni aslinya tidak pernah dibubuhi nama atau tanda lain sebagai pengenal penciptanya. Mendiang Ida Bagus Nyana, termasuk tokoh pematung Bali terkemuka yang dikenal ciri halus kreasinya, tidak pernah menandai karya pribadinya. Pematung terkenal Cokot semasa hidupnya sudah banyak ditiru orang coraknya dan kini dapat dipesan dengan mudah. Lukisan corak "naif" yang dimulai oleh seseorang di Ubud, kini dilakukan oleh sekelompok orang. Pada intinya tiru meniru dalam kehidupan seni masyarakat tradisional tidak pernah dirisaukan dan dipermasalahkan. Kebiasaan tidak mencantumkan nama pada suatu karya cipta dalam masyarakat tradisional berlaku di seluruh tanah air. Banyak ceritacerita rakyat seperti pewayangan di Jawa, ceritera randai di Sumatera Barat, tidak dikenal penciptanya. Arsitektur rumah-rumah adat tradisional, karya sastra pantun, tambo dan lainnya, juga tidak diketahui penciptanya. ${ }^{28}$

Dalam masyarakat tradisional suatu karya cipta yang telah diumumkan kepada masyarakat langsung menjadi milik bersama (public domein). Siapa saja boleh meniru dan mencontoh ciptaan tersebut, dan penciptanya juga tidak mempermasalahkan. Ciri khas masyarakat tradisional adalah sifat kolektif atau kebersamaan. Hak cipta tidak mempunyai akar budaya dalam masyarakat tradisional. Nilai falsafah yang mendasari pemilikan

${ }^{28}$ Haryati Soebadio."Aspek Sosial Budaya Hak Milik Perindustrian", Makalah, HIm. 5. 
individu terhadap suatu karya cipta manusia, baik di bidang IImu pengetahuan, sastra maupun seni adalah nillai budaya barat yang menjelma dalam sistem hukumnya.

\section{Simpulan}

Dari uraian yang membahas tentang nilainilai hak cipta dan problematik perlindungan hukumnya dapat ditarik simpulan sebagai berikut: Konsep hak cipta tidak dikenal dalam masyarakat tradisional Indonesia. Hak cipta sebagai bagian dari HAKI, semula dikenal di negara barat dan masuk di Indonesia bersamaan dengan penjajahan. Nilai-nilai budaya masyarakat Indonesia tidak mengenal pemilikan individu terhadap suatu karya cipta dalam bidang ilmu pengetahuan, sastra, dan seni. Satu-satunya sistem pemilikan yang melembaga dalam kehidupan masyarakat tradisional adalah pemilikan tanah. Namun pemilikan itu sifatnya komunal, artinya dimiliki oleh keluarga atâu masyarakat hukum adatnya. Oleh karena itu perlindungan hukum di bidang hak cipta akan banyak menghadapi hambatan, terutama hambatan yang bersifat kultural. Perlu sosialisasi dan pembudayaan hak cipta kepada masyarakat, sehingga masyarakat mengetahui, bersikap positif dan menghormati hak cipta.

\section{Daftar Pustaka}

Damian, Eddy. 1999. Hukum Hak Cipta Menurut Beberapa Konvensi Internasional, UU Hak Cipta 1997, dan Perlindungannya terhadap Buku serta Perjanjian Penerbitan. Bandung: Alumni.
Hadikusuma, Hilman. 1992. Pengantar IImu Hukum Adat Indonesia. Bandung: CV Mandar Maju.

Hutagalung, Sophar Maru. 1994. Hak Cipta Kedudukan dan Peranannya di dalam Pembangunan. Edisi pertama. Jakarta: Akademika Pressindo.

Jened, Rahmi. 2001. Perlindungan Hak Cipta Pasca Persetujuan TRIPs. Surabaya: Yuridika Pres Fak. Hukum Unair Surabaya.

Kintner, Earl W. dan Jack Lahr. 1983. An Intellectual Property Law Primer. New York: Clark Boardman.

Luthan, Salman. 1989. "Delik Hak Cipta". Makalah Diskusi Jurusan Hukum Pidana FH UII. Tanggal 24 Agustus. 1989

M. Jumhana dan R Djubaedillah. 1993. Hak Milik Intelektual sejarah, Teori dan Prakteknya. Bandung: Citra Aditya Bhakti

Maryadi. 2000. Transformasi Budaya. Ctk. Pertama, Surakarta: Muhammadiyah University Press.

Martin Khor Kok Peng. 1993. Imperialisme Ekonomi Baru: Putaran Uruguay dan Kedaulatan Dunia Ketiga. Jakarta: PT Gramedia Pustaka Utama dan Konphalindo.

Rahardjo, Satjipto. 1982. IImu Hukum. Bandung: Alumni.

Saidin. 1995. Aspek Hukum Hak kekayaan Intelektual (Intelectual Property Right). Jakarta: PT Raja Grafindo Persada. 
Soebadio, Haryati."Aspek Sosial Budaya Hak Milik Perindustrian." Makalah

Sutrisno, Nandang. 1999. "Implementasi

- Persetujuan TRIPs dalam UndangUndang Hak Cipta Indonesia." Jurnal Hukum No.12 Vol. 6-1999

Zainudin, Imam Buchori. "Konsepsi Seni Rupa dalam Kaitannya dengan Hak
Cipta." Makalah pada Temu Wicara Mengenai Hak Cipta antara Seniman, Sastrawan, IImuwan, dan Organisasi Profesi di Bidang Hak Cipta. Jakarta: 28-29 Juli 1997,

.Undang-Undang Nomor 12 Tahun 1997 tentang Hak Cipta (LN RI tahun 1997 Nomor 29). 